\title{
Native and endangered timber tree species in home gardens of Northeast and Northcentral Vietnam
}

\begin{abstract}
Homegardens are receiving increasing attention for in-situ plant genetic conservation in biodiversity conservation programs. To inform authorities and conservation stakeholders, we investigated the diversity and provenance type of tree species in 120 homegardens in Northeast and Northcentral Vietnam. The study showed that ten of sixteen recorded timber trees are native to the country, including one (Aquilaria crassna) classified as 'critically endangered', two 'endangered' (Erythrophleum fordii and Parashorea chinensis), and one 'vulnerable' (Dalbergia tonkinensis), according to the global Red List of threatened tree species. The study provides evidence for the potential role of homegardens as plant genetic source and in-situ conservation, and we recommend that the Government of Vietnam recognizes this opportunity through support programs for diversification and domestication of native tree species for homegardens.
\end{abstract}

Keywords: Agro-biodiversity, conservation status, homegarden, in-situ conservation, native tree species

\section{Introduction}

Agro-biodiversity is the result of natural and human selection processes involving animal, plant, and micro-organisms in agricultural systems, and is important for determining the socio-economic and ecological benefits that can be derived from the systems. ${ }^{1}$ The trend of developing mono culture agricultural systems for the sake of high productivity and economic return, however, has led agro-biodiversity into alarming level. ${ }^{2}$ Despite theglobal trend, homegarden can become anavenue for investigating on-farm plant genetic resources since they often serve as refuge for native plant species and act as experimental sites when introducing new species/varieties. ${ }^{3}$ While the socio-economic and ecological benefits of homegardens arerelatively wellknown, nonetheless, more research is needed to understand their contributions to agro-biodiversity and in-situ conservation., ${ }^{4,5}$

To avoid further degradation in current agro-biodiversity, and biological diversity in general, Vietnam has demonstrated commitment to international biodiversity conservation treaties such as Convention on Biological Diversity (CBD) by formulating conservation strategies promulgated by the Ministry of Natural Resource and Environment (MONRE). For example, in the National Biodiversity Strategy to 2020 and Vision to 2030, the government aims to conserve 'naturally important ecosystems, endangered, rare, and precious species, and genetic resources; that should be used sustainably, and contribute to the development of a green economy, and actively respond to climate change'. ${ }^{6}$ Specifically, the target is 'to improve the quality and population of endangered, rare and precious plant and animal species, ensuring that no new case of species extinction is reported, and significantly improve the status of endangered, rare and threatened species' and 'to compile an inventory, store, and conserve native, endangered, rare and precious genetic resources to ensure that they are not impaired or eroded.

To achieve the target, the CBD and the National Biodiversity Strategy emphasize in-situ and the complementarity between in-situ and ex-situ conservation approaches for conserving and ensuring sustainable uses of biodiversity, and ensuring fair and equitable benefit share from the use of genetic resources. In contrast to $e x-$
Volume 2 Issue I - 2018

Mulia R, Simelton E, Le TT, Pham TV, Do TH
World Agroforestry Centre,Vietnam Country office,Vietnam

Correspondence: Rachmat Mulia, World Agroforestry Centre, Viet Nam Country office, Tel +84 43783 4644/5,

Email r.mulia@cgiar.org

Received: November 03, 2017| Published: January 23, 2018 situ, in-situ conservation allows the plant evolution and adaptation process to continue in its natural habitat, and become the subject of continuous research. ${ }^{5}$ Moreover, italso enables learning and sharing interactions between landowners, researchers, extension service and local authorities, including on the importance of conservation. ${ }^{5}$ Despite all of these, the Vietnam National Biodiversity Strategy has indeed paid little attention to the potential role of homegarden as plant genetic source and in-situ conservation.

There are some policies in Vietnam, both at province and district level supporting homegarden development, for example Resolution No. 01/ NQ-HDND issued on August $5^{\text {th }} 2016$ and Resolution No. 32/NQ-HDND issued on December $15^{\text {th }} 2016$ for Ha Tinh province, Northcentral Vietnam. These policies were promulgated to meet the targets of New Rural Development Program (Decision No. 1600/ QĐ-TTg issued on August 16" 2016) and "Agricultural restructuring towards raising added values and sustainable development" program (Decision No.899/QĐ-TTg issued on June 10 th 2013). These policies however mainly focus on enhancing economic benefits of homegarden, for example by subsidizing seedlings of fruit trees, and formulating targeted income from supported homegardens.

The aim of our study was to document the diversity and provenance type (native vs. exotic) of tree species in homegardens of upland communities in Northeast and Northcentral Vietnam. We focus on the provenance type and endangered status of recorded tree species in the two regions, while links between tree diversity and drivers that lead to the diversity, which has beena focus of existing studies about Vietnamese homegardens ${ }^{7-10}$ will be covered in another paper. To our knowledge, for the case of Vietnamese homegarden, none has conducted similar study like we present here. We also aimed to provide evidence for the Government of Vietnam to pay more attention to the potential role of homegardens as plant genetic source and in-situ conservation.

\section{Study area}

In total 120 homegardens from four sampled communes, with 30 homegardens per commune, were investigated. In the Northeast region, the study sites are found in Dong Phuc and Hoang Tri communes, Ba 
Be district, Bac Kan (BK) province $\left(22^{\circ} 10^{\prime} \mathrm{N} 105^{\circ} 50^{\prime} \mathrm{E}\right)$. Ba Be is a mountainous district with nearly $95 \%$ of its population from ethnic minorities such as Tay, Dao, and Mong. ${ }^{11}$ In the Northcentral region, the study sites were selected in Ky Son commune, Ky Anh district and Huong Lam commune, Huong Khe district, Ha Tinh (HT) province $\left(18^{\circ} 20^{\prime} \mathrm{N} 105^{\circ} 54^{\prime} \mathrm{E}\right)$. Both districts are coastal upland with nearly the whole population from the majority Kinh ethnic group.

\section{Methods}

Thehousehold selection was conducted with a stratified random samplingof 2-3villages per commune. The information documented from each homegarden included vernacular name andnumber of standing trees of each tree species. First, the recorded tree species wereclassified into (a) timber trees, defined as those producing wood and/or bark as main product, or (b) non-timber trees, those for other purposes, e.g.providing fruits. Next, each tree species is classified into native or exotic, based on local and scientific knowledge. Local knowledge here refers to if the tree species is native to the commune or originated from other areas, and was based on interviews with local key informants, e.g. extension officer sand commune leaders. Scientific knowledge determinesthe status to the country, and is based on the global classification by International Union for Conservation of Nature (IUCN) (http://www.iucnredlist.org/) or the Catalogue of life (http://www.catalogueoflife.org/). The $\mathrm{IUCN}^{12}$ defines native species as 'a species, subspecies, or lower taxon, occurring within its natural range (past or present) and dispersal potential (i.e. within the range it occupies naturally or could occupy without direct or indirect introduction or care by humans)', and exotic species as the opposite. Furthermore, for tree species classified as native to the country, we used the IUCN Red List of threatened tree species (http://www. iucnredlist.org/) to figure out their conservation status. In the Red list,the 'threatened status' includes 'crictically endangered' defined as 'extremely high risk of extinction in the wild', 'endangered' as 'high risk of extinction in the wild', 'vulnerable' as 'high risk of endangerment in the wild', while 'lower risk' denotes 'least concern'.

For each commune, we calculated the abundance rate of each timber tree species that reflects the number of standing trees of a timber tree species relative to total number of standing trees of all timber tree species recorded in all sampled households of the commune. We also calculatedthe number of households that cultivate the timber tree species, and determined their provenance type based on local and scientific knowledge, and the conservation status based on the Red List.

\section{Results and discussion}

The survey documented in total 56 tree species, in which 40 were non-timber tree species dominated by fruit trees, e.g. mango, pomelo, jackfruit, plum and guava, and 16 timber tree species (Table 1). In BK province, Melia azedarach was found in 12 of 30 households in Dong Phuc commune and 8 of 30 households in Hoang Tri commune, with the abundance rate of $33 \%$ and $68 \%$ respectively. Other species with high abundancerate included Manglietia conifera and Chukrasia tabularis. In HT province, Acacia mangium and Aquilaria crassna were found in 11 and 20 of the sampled 30 households in Huong Lam commune respectively, with theabundance rate of $52 \%$ and $46 \%$ respectively. In Ky Son commune, Acacia mangium was found in two sampled households only but its abundance rate was $97 \%$ because the two households cultivate the Acacia trees in plantations (Table 1). If the two households were excluded from the analysis, the abundance rate was $88 \%$ for Aquilaria crassna and $10 \%$ for Melia azedarach.

Table I Diversity and provenance type of timber tree species in homegardens of Bac Kan and $\mathrm{Ha}$ Tinh province $(\mathrm{n}=\mathrm{I} 2 \mathrm{HH})$

\begin{tabular}{|c|c|c|c|c|c|c|c|c|c|c|c|c|c|c|}
\hline \multirow{2}{*}{$\begin{array}{l}\text { Species name } \\
\text { Scientific }\end{array}$} & \multirow[b]{2}{*}{ Vernacular } & \multirow[b]{2}{*}{ English } & \multicolumn{2}{|c|}{$\begin{array}{l}\text { Dong phuc } \\
(n=30 \mathrm{HH})\end{array}$} & \multirow[b]{2}{*}{ Status $^{++}$} & \multicolumn{2}{|c|}{$\begin{array}{l}\text { Hoang tri } \\
(n=30 \mathrm{HH})\end{array}$} & \multirow[b]{2}{*}{ Status } & \multicolumn{2}{|c|}{$\begin{array}{c}\text { Huong lam } \\
(n=30 \mathrm{HH})\end{array}$} & \multirow[b]{2}{*}{ Status } & \multicolumn{2}{|c|}{$\begin{array}{l}\text { Ky son } \\
(n=30 H H)\end{array}$} & \multirow[b]{2}{*}{ Status } \\
\hline & & & A*(\%) & $\mathbf{H H}^{+}$ & & A (\%) & $\mathbf{H H}$ & & A (\%) & $\mathbf{H H}$ & & A (\%) & HH & \\
\hline Acacia mangium & Keo & Acacia & & & & & & & 52 & 11 & $\mathrm{E}, \mathrm{E}$ & 97 & 2 & $\mathrm{E}, \mathrm{E}$ \\
\hline $\begin{array}{l}\text { Aquilaria } \\
\text { crassna }\end{array}$ & Dó trầm & Agarwood & & & & & & & 46 & 20 & $\mathrm{~N}, \mathrm{~N}$ & 2 & 12 & $\mathrm{~N}, \mathrm{~N}$ \\
\hline $\begin{array}{l}\text { Chukrasia } \\
\text { tabularis }\end{array}$ & Lát hoa & $\begin{array}{l}\text { Indian } \\
\text { mahogany }\end{array}$ & 23 & 4 & $\mathrm{~N}, \mathrm{~N}$ & 3 & 1 & $\mathrm{~N}, \mathrm{~N}$ & & & & & & \\
\hline $\begin{array}{l}\text { Cinnamomum } \\
\text { cassia }\end{array}$ & Quế & Cinnamon & & & & & & & 0.01 & 1 & $\mathrm{~N}, \mathrm{E}$ & & & \\
\hline $\begin{array}{l}\text { Dalbergia } \\
\text { tonkinensis }\end{array}$ & Sưa & Sua tree & 6 & 3 & $\mathrm{~N}, \mathrm{~N}$ & 4 & 1 & $\mathrm{~N}, \mathrm{~N}$ & 1.4 & 4 & $\mathrm{~N}, \mathrm{~N}$ & & & \\
\hline $\begin{array}{l}\text { Duabanga } \\
\text { grandiflora }\end{array}$ & Cây phay & - & 3 & I & $\mathrm{N}, \mathrm{N}$ & & & & & & & & & \\
\hline $\begin{array}{l}\text { Erythrophleum } \\
\text { fordii }\end{array}$ & Lim xanh & Ironwood & & & & & & & 0.3 & 2 & $\mathrm{~N}, \mathrm{~N}$ & & & \\
\hline Eucalyptus spp. & Bạch đàn & Eucalyptus & & & & & & & & & & 0.01 & 2 & $\mathrm{E}, \mathrm{E}$ \\
\hline $\begin{array}{l}\text { Khaya } \\
\text { senegalensis }\end{array}$ & Xà cừ & African maho & fany & & & & & & 0.02 & I & $\mathrm{N}, \mathrm{E}$ & 0.01 & 1 & $\mathrm{E}, \mathrm{E}$ \\
\hline $\begin{array}{l}\text { Manglietia } \\
\text { conifera }\end{array}$ & Mỡ & - & 35 & 3 & $\mathrm{~N}, \mathrm{~N}$ & 24 & I & $\mathrm{N}, \mathrm{N}$ & & & & & & \\
\hline $\begin{array}{l}\text { Melia } \\
\text { azedarach }\end{array}$ & Xoan & Chinaberry & 33 & 12 & $\mathrm{~N}, \mathrm{~N}$ & 68 & 8 & $\mathrm{~N}, \mathrm{~N}$ & 0.3 & 5 & $\mathrm{~N}, \mathrm{~N}$ & 0.01 & 5 & $\mathrm{~N}, \mathrm{~N}$ \\
\hline $\begin{array}{l}\text { Oroxylum } \\
\text { indicum }\end{array}$ & Nút nác & $\begin{array}{l}\text { Trumpet } \\
\text { flower }\end{array}$ & 0.1 & 1 & $\mathrm{~N}, \mathrm{~N}$ & & & & & & & & & \\
\hline $\begin{array}{l}\text { Parashorea } \\
\text { chinensis }\end{array}$ & Chò chỉ & - & & & & & & & & & & 0.01 & 1 & $\mathrm{~N}, \mathrm{~N}$ \\
\hline
\end{tabular}


Table Continued.

\begin{tabular}{|c|c|c|c|c|c|c|c|c|c|c|c|c|c|c|}
\hline \multicolumn{3}{|l|}{ Species name } & \multicolumn{3}{|c|}{$\begin{array}{l}\text { Dong phuc } \\
(n=30 \mathrm{HH})\end{array}$} & \multicolumn{3}{|c|}{$\begin{array}{l}\text { Hoang tri } \\
(n=30 \mathrm{HH})\end{array}$} & \multicolumn{3}{|c|}{$\begin{array}{l}\text { Huong lam } \\
(n=30 \mathrm{HH})\end{array}$} & \multicolumn{3}{|c|}{$\begin{array}{l}\text { Ky son } \\
(\mathrm{n}=30 \mathrm{HH})\end{array}$} \\
\hline Scientific & Vernacular & English & $A^{*}(\%)$ & $\mathbf{H H}^{+}$ & Status $^{++}$ & A (\%) & HH & Status & A (\%) & $\mathbf{H H}$ & Status & A (\%) & HH & Status \\
\hline Pinus spp. & Thông & Pine & & & & & & & 0.01 & 1 & $\mathrm{~N}, \mathrm{~N} / \mathrm{E}$ & & & \\
\hline Senna siamea & Muồng đen & Kassod tree & & & & 1 & I & $\mathrm{N}, \mathrm{E}$ & & & & & & \\
\hline $\begin{array}{l}\text { Symplocos } \\
\text { laurina }\end{array}$ & Cây dung & - & & & & & & & 0.04 & 2 & $\mathrm{~N}, \mathrm{~N}$ & & & \\
\hline
\end{tabular}

*A, Abundance Rate; ${ }^{+} \mathrm{HH}$, Number of Households Cultivate the Tree Species; ${ }^{++}$Status of specie $(\mathrm{N}=$ native or $\mathrm{E}=$ exotic to commune, to the country)

There were some disagreements between native and exotic origin, according to the local and scientific knowledge. From the 16 recorded timber tree species in both provinces, thirteen species were claimed as native to the commune according to key informants, while only ten trees are stated native to the country, according to the IUCN list (Table 1). Two tree species namely Cinnamomum cassia and Senna siamea were claimed as native to the commune, but exotic according to IUCN. Another species namely Khaya senegalensis was claimed as native by the key informants in Huong Lam commune, and exotic by those in Ky Son commune. According to IUCN, this tree species is exotic to the country.

While none of the 40 recorded non-timber tree species are found in the IUCN Red List of threatened tree species, eight of the 16 recorded timber speciesare found in the List. Out of those the status of four is of higher concern than 'lower risk': Aquilaria crassna is 'critically endangered', Erythrophleum fordii and Parashorea chinensis are 'endagered', and Dalbergia tonkinensis is 'vulnerable', while the four with 'lower risk' status are Alstonia scholaris, Chukrasia tabularis, Ficus carica, and Manglietia conifera.

Aquilaria crassna can reach up to $15-20 \mathrm{~m}$ at mature stage, and a stem diameter of $40-50 \mathrm{~cm} .{ }^{13}$ Members of Aquilaria spp. can produce a fragrant agarwood, namely a resinous heartwood that is often used for perfume and incense. The resin is produced as response to a mould infection by Phaeoacremonium parasitica. ${ }^{14}$ In Vietnam, wild Aquilaria in forests has been over extracted, which is why farmers in some provinces such as HT collected the seedlings from natural forests to cultivate in homegardens. ${ }^{13}$

Erythrophleum fordii is a valuable hardwood species in Vietnam threatened by over exploitation for its timber. ${ }^{15}$ Itgrows mainly in northern and central Vietnam. The tree can reach $37-45 \mathrm{~m}$ in height and $200-250 \mathrm{~cm}$ in diameter. It is often called 'ironwood', and its quality wood can be used for flooring planks, construction, and long duration transport facilities. ${ }^{16}$ Parashorea chinensis can reach $80 \mathrm{~m}$ in height ${ }^{17}$ and more than $100 \mathrm{~cm}$ in stem diameter, hence becomes part of the top canopy in dense tropical forests. Its growing habitat is mainly in northern Vietnam, but has been decimated due to deforestation and over exploitation. ${ }^{18}$

Dalbergia tonkinensis or 'sua tree', named after its vernacular name in Vietnamese, is a valuable timber tree species despite its comparatively low height, namely $5-13 \mathrm{~m}$ for mature trees. This species is native to China and Vietnam, and threatened by habitat loss and overexploitation for its valuable timber. ${ }^{19}$ Aquilaria crassna was also found in homegardens of Central Vietnam. ${ }^{10}$ The existing studies of Vietnamese homegardens that we reviewed [e.g. 7-10, 20] did not report any record of Erythrophleum fordii, Parashorea chinensis, and Dalbergia tonkinensis trees in their sampled homegardens.

\section{Conclusion and recommendations}

The homegardens in the Northeast and Northcentral Vietnam accomodated native and endangered timber tree species, and therefore policy support for homegarden development should not lead to highly commercial and monoculture oriented homegardens that can threaten the role of homegarden as in-situ plant genetic source and conservation for diversity and domestication of native tree species. Homegardens should easily lend themselves to farmer's backyard as experiment sites. The current homegarden policies prioritize higher economic benefits, but they should actually be in line with the National Biodiversity Strategy that supports both in-situ and exsitu conservation, although currently the former primarily relates to special-use forest as conservation sites. However, the National Biodiversity Strategy also encourages 'on-farm conservation'. The national and international classification lists of native endangered tree species should be coordinated. For example, Aquilaria crassna is in the MONRE's list of endangered species ${ }^{6}$ but we found Erythrophleum fordii and Parashorea chinensis which are classified as 'endangered' in the Global Red List are absent from the list.

\section{Acknowledgements}

The tree species documentation was conducted through funding from the International Fund for Agricultural Development (IFAD) and Forest, Tree and Agroforestry (FTA) program for the documentation in Huong Lam commune, the CGIAR Research Program on Climate Change, Agriculture and Food Security (CCAFS) for Ky Son commune, and the Norwegian Agency for Development Cooperation (NORAD) for the two communes in Bac Kan province. We thankDuong Minh Tuan for data collection and Nguyen Tuan Anh for helping in data analysis.

\section{Conflict of interest}

The authors declare that there is no conflict of interest regarding the publication of this article.

\section{References}

1. Thrupp LA. Linking biodiversity and agriculture: Challenges and opportunities for sustainable food security. World Resources Institute, USA; 1997.

2. CBD. Global Biodiversity Outlook 2. Convention on Biological Diversity, Canada; 2006. p. 1-92.

3. Eyzaguirre P, Martin GJ, Barrow S. Growing diversity, conserving plant genetic resources. People and Plants, UNESCO, Paris, WWF, Gland, Switzerland; 2001.

4. Agbogidi OM, Adolor EB. Home gardens in the maintenance of biological diversity. App Sci Rep. 2013;1(1):19-25. 
5. Engels J. Home gardens-a genetic resources perspective. In: Watson JW, Eyzaguirre PB, editors. Home gardens and in situ conservation of plant genetic resources in farming systems. Proceedings of the Second International Home Gardens Workshop, Witzenhausen, Germany; 2002.

6. MONRE. Viet Nam national biodiversity strategy to 2020, Vision to 2030. Ministry of Natural Resources and Environment, Ha Noi, Viet Nam. 2014.

7. Mohri H, Lahoti S, Saito O, et al. Assessment of ecosystem services in homegarden systems in Indonesia, SriLanka, and Viet Nam. Ecosystem Services. 2013;5:124-136.

8. Timsuksai P, Nguyen DT, Rambo AT. Homegardens of the Cao Lan, a Tai-speaking ethnic minority in Viet Nam's northern mountains. Southeast Asian Studies. 2015;4(2):365-383.

9. Trinh LN, Watson JW, Huec NN, et al. Agrobiodiversity conservation and development in Vietnamese home gardens. Agriculture, Ecosystems and Environment. 2003;97(1-3):317-344

10. Vlkova M, Polesny Z, Verner V, et al. Ethnobotanical knowledge and agrobiodiversity in subsistence farming: case study of home gardens in Phong My commune, Central Viet Nam. Genet Resour Crop Evol. 2011;58(5):649-644.

11. People's committee of Bac Kan. General overview of natural conditions in $\mathrm{Ba} \mathrm{Be}$ district, Vietnam; 2012.

12. IUCN. IUCN guidelines for the prevention of biodiversity loss caused by alien invasive species. International Union for Conservation of $\mathrm{Na}$ ture. Gland Switzerland; 2000.
13. Hoang TL, Nguyen DTL. Conservation and use of Aquilaria crassna in Viet Nam: a case study. Central Forest Seed Company, Hanoi, Vietnam; 2002.

14. Crous PW, Gams W, Wingfield MJ, et al. Phaeoacremonium gen. nov. associated with wilt and decline diseases of woody hosts and human infections. Mycologia. 1996;88(5):786-796.

15. Sein CC, Mitlohner R. Erythrophloeum fordii Oliver: ecology and silviculture in Vietnam. Center for International Forestry Research. Bogor, Indonesia; 2011.

16. FSIV, JICA. Use of indigenous tree species in reforestation in Viet Nam. Forest Science Institute of Viet Nam, Japan International Cooperation Agency, Agricultural Publishing House, Hanoi, Vietnam; 2003.

17. Ashton P. Parashorea chinensis. The IUCN Red List of Threatened Species. International Union for Conservation of Nature and Natural Resources. Gland, Switzerland; 1998.

18. Pham DC, Zuidema PA, Nguyen HN. Conservation prospects for threatened Vietnamese tree species: results from a demographic study. Popul Ecol. 2008;50(2):227-237.

19. Ban NT. Dalbergia tonkinensis. IUCN Red List of Threatened Species. International Union for Conservation of Nature, Gland, Switzerland; 1998.

20. Vu TM, Mizuno K, Funakawa S, et al. Homegarden practice and crop contribution to livelihood in mountainous villages of Central Viet Nam. Trop Agr Develop. 2015;59(3):118-126. 